\title{
Los Voluntarios de Fernando VII de Ciudad de México. ¿Baluarte de la capital y confianza del reino?
}

\author{
por \\ Jesús Ruiz de Gordejuela Urquijo \\ Universidad Rey Juan Carlos
}

La presente investigación pretende acercarnos a la milicia urbana de los Voluntarios de Fernando VII de ciudad de México, en un primer momento como cuerpo de choque en el golpe de Estado del 16 de septiembre de 1808 y dos años después como garante de la seguridad de la capital virreinal hasta su disolución en vísperas de la independencia mexicana. Gracias a fuentes primarias inéditas hemos podido adentrarnos en la vida de este polémico cuerpo militar jalonado de escándalos y graves problemas internos y descubrir si realmente fueron el baluarte de la capital y la confianza del reino tal y como pretendió su coronel el virrey Calleja.

Palabras clave: Voluntarios de Fernando VII; Ciudad de México; milicias urbanas; golpe de estado; insurgencia; orden público.

\section{INTRODUCCIÓN $^{1}$}

Una avalancha de noticias llegó a la capital novohispana a partir de la primavera de 1808 sorprendiendo a su confiada población. El Motín de Aran-

${ }^{1}$ La producción historiográfica mexicana en torno a este cuerpo miliciano no es muy numerosa, quizás debido a que las investigaciones se centraron más en el discurso nacional y en sus héroes que en profundizar en el estudio de sus contrarios. Su decisiva participación en la destitución por la fuerza del virrey José de Iturrigaray quedó reflejada en las crónicas de los más célebres estudiosos mexicanos del siglo XIX, tales como Lucas Alamán, Lorenzo de Zavala o José Servando Teresa de Mier. En 1877 Juan E. Hernández y Dávalos sacó a la luz su Colección de Documentos para la Historia de la Guerra de Independencia de México de 1808 a 1821, importante aportación a la historia de esta nación, que fueron completados años después por Genaro García con sus Documentos Históricos Mexicanos, obra conmemo- 
juez por el que Carlos IV renunciaba al trono provocó un espontáneo movimiento cívico en defensa de la religión, del rey y de la patria que se agudizaría aún más cuando se supo que los miembros de la familia real abandonaron España y, que el pueblo de Madrid se levantó en armas contra el invasor francés. Si estas noticias alarmaron a los novohispanos, las renuncias de los distintos miembros de la familia real a la Corona española en favor de Napoleón supuso un punto y aparte en las relaciones entre los criollos y la metrópoli. Ante el peligro de que la colonia fuera asimismo invadida, una ola de patriotismo compuesto por todos los grupos sociales se ofreció a integrar los distintos cuerpos milicianos. Así, las plazas de las principales ciudades del virreinato se despertaron empapeladas con pasquines en los que se convocaba a formar parte de los nuevos cuerpos armados, tal y como ocurrió en Puebla en donde «se habían presentado voluntariamente gran número de ciudadanos y del pueblo para alistarse a las armas». En tan solo dos días acudieron en esta ciudad 2.000 hombres «ofreciéndose gustosos a la formación de un Regimiento de Infantería y pidiendo que fuese bajo los auspicios y título de Voluntarios de Fernando VII $»^{2}$. A pesar de este febril patriotismo, los ciudadanos más destacados de la ciudad no estaban dispuestos a mezclarse con el resto del pueblo por lo que se ofrecieron a formar su propio cuerpo de milicias distinto y diferenciado del resto de la población con el ostentoso título de Voluntarios de nobles patricios de Fernando VII.

Las principales instituciones de la capital también se sumaron a este patriotismo y la noticia del levantamiento del pueblo español contra los franceses, animó al prestigioso Real Cuerpo de Minería a ofrecer al virrey la entrega de cien piezas de artillería de campaña y comprometerse a levantar ocho compañías de ochenta hombres cada una. Las repúblicas de naturales no quisieron permanecer al margen de este movimiento y, de este modo, los indios de Chalco, Querétaro, Guadalajara, Jalapa, Veracruz y las parcialidades

rativa del primer centenario de la Independencia, ambas obras imprescindibles para el estudio de este primer cuarto del siglo XIX mexicano. Los artículos de la historiadora Virginia Guedea "Criollos y Peninsulares", "El pueblo de México y la política capitalina, 1808-1812" y "Los indios Voluntarios de Fernando VII" y, las más recientes publicaciones del profesor Jesús Ruiz de Gordejuela, "El largo verano de 1808 en México. El golpe de Gabriel de Yermo" y El vizcaíno Gabriel de Yermo y los Voluntarios de Fernando VII nos invitan a conocer a este cuerpo del ejército realista. Esta investigación se complementa con la documentación original del Archivo General de la Nación de México, que nos ha permitido descubrir de primera mano los graves problemas que afrontó este cuerpo miliciano a lo largo de sus 18 años de existencia.

2 Landavazo Arias, 2001: 117-118. Para conocer más sobre la presencia de los indios en las milicias, podemos consultar el trabajo de Guedea, 1986: 11-83. 
indígenas de San Juan y de Santiago se prestaron a crear sus propias compañías de voluntarios. Los ofrecimientos fueron tan espontáneos y numerosos en todo México que el virrey Iturrigaray ordenó la creación de un cuerpo en las principales plazas del virreinato con el nombre de «Voluntarios de Fernando VII». Para llevar a cabo esta misión en la ciudad de México, durante los primeros días del mes de agosto, el virrey delegó en los ayudantes de la plaza, Francisco Barroso y el conde de Columbini, quienes se encargarían de adiestrar en el manejo de las armas a todos aquellos que se presentasen como voluntarios. El ejemplo de la capital pronto tuvo su reflejo en distintas regiones del virreinato, tal y como solicitaron los cajeros del comercio de San Luis Potosí que en palabras del brigadier Calleja al virrey decía: «Los cajeros de este comercio seguidos de un numeroso Pueblo se me presentaron reunidos el 15 del corriente agosto a la salida del Templo con la adjunta solicitud dirigida a que todos ellos organizase una compañía de Caballería con la denominación de Voluntarios de Fernando VII para servir sin reserva en las actuales circunstancias del modo que disponga el superior gobierno» ${ }^{3}$, o el importante recibimiento que la población de Guadalajara hizo a esta convocatoria como señaló el regente de la Audiencia, Roque Abarca, que en solo dos días y medio alcanzaron los 2.560 voluntarios.

Los criollos, partícipes como el resto de la sociedad en este movimiento patriótico, vieron en este interregno la oportunidad de ser ellos mismos quienes manejasen las riendas del virreinato. El reconocimiento de los derechos políticos novohispanos parecía un hecho ya irrenunciable y por primera vez se habló de unas «leyes fundamentales» de la Nueva España. El Cabildo de ciudad de México, compuesto mayoritariamente por criollos, reivindicó para sí, no solo la soberanía de la Monarquía acéfala, sino también la constitución del reino. Esta interpretación chocó frontalmente con los preceptos defendidos por la Audiencia que se reservaba toda decisión que afectara al futuro de la colonia. El virrey Iturrigaray convocó una junta representativa del reino en la capital para el día 6 de agosto. En esta participarían todas las instituciones virreinales además de los Ayuntamientos y miembros de la Audiencia o también llamado Real Orden. El virrey solicitó a este último que en virtud de sus facultades jurídicas, le aconsejara el modo mejor a realizar esta junta general de todo el reino. La Audiencia no tardó en responderle y el 6 de sep-

3 Carta dirigida al virrey José de Iturrigaray y remitida por el coronel Félix María Calleja, informándole de que los cajeros del comercio de San Luis Potosí le presentaron una solicitud para organizar una compañia de Caballería como Voluntarios de Fernando VII, Archivo General de la Nación, México (AGN), Instituciones Coloniales, Indiferente Virreinal, caja 3737. 
tiembre de 1808 el virrey recibió el informe en el que se rechazaba de modo absoluto esta convocatoria, al juzgar que ello supondría convocar unos Estados generales novohispanos. Iturrigaray hizo caso omiso y decidió su celebración para tres días más tarde. Este paso adelante produjo entre los españoles europeos la primera señal de alarma, ya no necesitaron más pruebas de que los criollos estaban decididos «a romper el vínculo secular de la Nueva España con la metrópoli, y por ende, la colonia no cumpliría sus obligaciones esenciales de contribuir con sus fuerzas físicas y morales al socorro de la metrópoli invadida» ${ }^{4}$, tal como opinaba el obispo de Valladolid, Manuel Abad y Queipo. Los ricos hombres de negocios del Consulado de Comerciantes de la capital novohispana pensaron que la única persona capaz y lo suficientemente agraviada para llevar a cabo el golpe de mano no podía ser otro que el rico hacendado vasco Gabriel Joaquín de Yermo y Bárcena.

Gabriel de Yermo y los golpistas septembrinos. El origen de los Primeros Voluntarios de Fernando VII

Yermo era un hombre respetado entre sus iguales, querido por sus empleados, con quienes llegó a tener importantes detalles filantrópicos y, sobre todo, fiel a la Corona. Lucas Alamán decía de él que «estaba avecindado en aquella capital un español natural de Vizcaya, de edad madura; respetado por su conducta y por el caudal muy considerable que había recibido de su mujer y aumentado mucho con su industria y trabajo; de grande influjo en la tierra caliente del valle de Cuernavaca, donde tenía extensas haciendas y en ellas gran número de esclavos [...] Llamábase don Gabriel de Yermo, y sobre él fue sobre quien echaron los ojos los principales comerciantes que formaban el partido español, no dudando que tendría las mismas ideas que ellos, y juzgándolo por su respetabilidad y energía, muy propio para ponerlo a su cabeza» ${ }^{5}$.

Una vez que los preparativos del golpe de estado estuvieron listos, el vasco dio cuenta de ello a la Audiencia esa misma tarde del 15 de septiembre de 1808. Los oidores Guillermo de Aguirre y Miguel Bataller, líderes del

${ }^{4}$ Opinión del obispo de Valladolid, don Manuel Abad y Queipo, sobre la destitución del señor Iturrigaray. El prelado manifestó que los juntistas «cometían delito de alta traición de primera clase $[\ldots]$ y aunque se hubiera ejecutado de buena fe y con voluntad de conservar para el rey estas posesiones, en nada disminuía el delito de alta traición». Hernández y Dávalos, 1878-1881, t. I., doc. 280: 616-617.

5 Alamán, 1942, volumen I: 156 y Ruiz de Gordejuela Urquijo, 2012: 33-45. 
partido español, pronosticaron su fracaso y se abstuvieron de intervenir, aunque prometieron absoluta reserva y aseguraron a los implicados que no serían perseguidos. Recordaba Yermo que para cumplir lo acordado se valió de «diversos sujetos de confianza por medio de los cuales en todo el día 15 del corriente quedaron citados con señalamiento de hora como quinientos europeos y algunos patricios todos resueltos a morir o vencer, y retomaron cuantas medidas parecieron oportunas para dar el golpe sin derramamiento de sangre, desgracia ni desorden. Reunidos, pues, en los pasajes señalados entraron en el palacio del virrey a los tres cuartos para la una de la mañana del día 16, y se apoderaron de los guardias, del virrey y de toda su familia, sin que hubiera más desgracia que la muerte de un granadero del Regimiento del Comercio.... $»^{6}$.

Mientras se producía el reconocimiento del nuevo virrey, en el patio del palacio de gobierno los asaltantes conformaron diez compañías de 150 hombres cada una y una compañía de artillería con 100 soldados, con la misión de custodiar la familia virreinal y proceder a la detención de los principales líderes del partido criollo. Esta unidad se autodenominaría los Voluntarios de Fernando VII y se distinguieron con un uniforme compuesto por chaqueta azul, collarín y vuelta encarnada, galoneada en redondo de oro, chaleco, pantalón blanco con bota, sombrero redondo y galón ancho. Esta pomposa vestimenta marcaría su futuro apodo por el que serían popularmente conocidos como «chaquetas», en clara alusión a la prenda que portaban muy parecida a las que utilizaban en los comercios en donde ejercían su oficio. El nombramiento de los oficiales reflejó el modelo de representación del sistema estamental altamente jerárquico que caracterizaba a la sociedad novohispana ${ }^{7}$. Es significativo tener en cuenta cómo los oficiales fueron elegidos del mismo modo a como se procedía en la elección de los cargos de gobierno del Consulado de comerciantes de ciudad México, es decir, alternando representantes vascos y cántabros. El grado de capitán estuvo reservado a comerciantes pertenecientes al Consulado pero que no representaban a la elite comercial novohispana, mientras que para los grados de teniente y subteniente encontramos un conjunto de comerciantes con pocos años de asentamiento en la capital y no con mucho peso específico dentro del conjunto de comerciantes de la ciudad 8 . Muy diferente sucedería en 1810 cuando se conformaron los Batallones Patrióticos Distinguidos de Fernando VII por orden del virrey

\footnotetext{
${ }^{6}$ Archivo Histórico Nacional, Madrid (AHN), Consejos, leg. 21.081, fol. 90.

7 Ruiz de Gordejuela, 2012: 118.

8 Véase cuadro en anexo 1. Ruiz de Gordejuela, 2010: 89-112.
} 
Venegas; entonces, el cuadro de oficiales sería ocupado por los comerciantes más pudientes y por la nobleza novohispana.

Tras la detención del virrey y de los líderes criollos, los voluntarios se encargaron de custodiar y trasladar a los detenidos al puerto de Veracruz en donde serían encarcelados mientras el virrey y su familia eran reenviados a la península. Para evitar cualquier reacción contraria, los voluntarios se responsabilizaron de velar por el orden público en la capital novohispana. La Audiencia sustituyó al malogrado Iturrigaray por el anciano mariscal José de Garibay. Un mes después del golpe de estado, el nuevo virrey ordenó la retirada de los cuerpos de Voluntarios de Fernando VII, temeroso de que estas fuerzas surgidas del núcleo más ortodoxo del realismo pudieran derrocarle, tal y como le había sucedido a su antecesor. Este presentimiento también lo heredó el siguiente virrey, el arzobispo de México Lizana y Beaumont, nombrado el 16 de febrero de 1809. El timorato obispo guardaba la sospecha de que los Voluntarios golpistas pudieran hacer lo mismo con él, por lo que el 3 de noviembre de este mismo año ordenó que las tropas de palacio estuvieran atentas a una posible revuelta armada de los «chaquetas». Los Voluntarios se sintieron traicionados y ante el rumbo que tomaba en España la causa abierta a Iturrigaray, tan contrario a lo que habían figurado, enviaron a su representante Marcos Antonio Berazaluce Echabe para que se presentase ante las autoridades peninsulares e informase con exactitud de todo lo ocurrido. El obispo-virrey interpretó que el objeto de este viaje podría ser la de solicitar su cese por lo que ordenó su detención y que «fuera llevado a la cárcel pública y tomando antes todas las medidas convenientes para evitar su evasión y coger sus papeles». Aunque Berazaluce, que portaba pasaporte firmado por el anterior virrey Garibay, pudo continuar viaje, falleció durante la travesía de vómito negro tres días después de su partida del puerto de Veracruz. El destino quiso que su sustituto, el cántabro Manuel Mier y Terán, sufriera la misma suerte.

De este modo el nombre de estos primeros Voluntarios de Fernando VII quedaría asociado al golpe de estado y a los abusos y desmanes de sus jóvenes integrantes. Dos años después, un nuevo cuerpo de Voluntarios se crearía con el objetivo de proteger a la capital de enemigos externos e internos pero esta vez con la participación de los españoles americanos.

Un nuevo escenario para los Voluntarios distinguidos de Fernando VII

La conformación de un cuerpo militar en la Nueva España en donde se integrasen las distintas castas y clases sociales ya lo había instituido José de 
Gálvez con las reformas militares entre 1765 y $1771^{9}$. A diferencia del Regimiento Urbano de Comercio de ciudad de México o el de los Voluntarios Distinguidos de Veracruz ${ }^{10}$ en donde todos sus componentes pertenecían a este gremio, integrar en una misma unidad miliciana a nobles, funcionarios, empleados del comercio y artesanos no era a priori tarea sencilla. A esta dificultad habría que añadir lo que nos advierte el profesor Christon Archer cuando dice que: «Para la mayoría de los caballeros locales nombrados para el mando de una compañía lo único que les importaba de las ordenanzas militares es la obediencia que le debían los subalternos» ${ }^{11}$ sin preocuparles demasiado su formación y entrenamiento.

Aunque las autoridades de la capital virreinal eran de la opinión de que todos sus ciudadanos debían participar en la defensa y protección de la res publica, las elites no veían con buenos ojos compartir este espacio público con otros que no fueran de su igual condición, los peninsulares desconfiaban de sus iguales americanos a quienes prejuzgaban al menos de autonomistas y a su vez, los criollos desconfiaban de la prepotencia de los españoles europeos, tal y como ocurrió durante y después de los acontecimientos de septiembre de 1808 .

Tras el grito a Dolores en septiembre de 1810, las tropas insurgentes avanzaron a tal ritmo que pronto tomaron las principales localidades del Bajío, y prestos se decidieron a tomar la capital del virreinato que no estaba protegida por ninguna milicia urbana. El recién nombrado virrey Venegas reunió a las autoridades más importantes de la capital el 4 de octubre de 1810 en el ayuntamiento de la ciudad de México. Allí se decidió que «se levantasen varios batallones con el nombre de Batallones Patrióticos Distinguidos de Fernando VII que sirvan para la tranquilidad, buen orden y demás fines del servicio del rey y del público de esta capital; siendo el coronel de todos ellos el mismo excelentísimo señor virrey» ${ }^{12}$. Para poder acceder a dicho cuerpo era requisito ser español, europeo como americano, y vecino de la ciudad de Mé-

9 Losa Contreras, 2006: 184.

${ }^{10}$ Lerdo de Tejada, 1857: 42. Este cuerpo creado en 1810 se disolvió en 1821.

11 Archer, 1983: 274.

12 Orden para la organización de batallones de Patriotas Distinguidos de Fernando VII, de los que es coronel el virrey. México a 5 de octubre de 1810. Hernández y Dávalos, 1878, tomo II, doc. n. ${ }^{\circ}$ 69. Las autoridades la conformaban el marqués de San Román (superintendente de la Real casa de Moneda de esta capital), Pedro María de Monterde (contador mayor del Real Tribunal y Audiencias de cuentas e intendente interino de esta ciudad y provincia), el coronel Ignacio José de la Peza y Casas (regidor perpetuo del Ayuntamiento) y el capitán Francisco Alonso Terán (Prior del Real Tribunal del Consulado en representación de su cuerpo). 
xico «desde la edad de diez y seis años en adelante que no estén ya ocupados en el servicio militar, y que tengan proporción para mantenerse a su costa en los días que estén empleados, y para hacerse un uniforme decente y de la sencillez que conviene». La junta pretendió que los primeros en alistarse fueran los miembros de la nobleza y los empleados de oficinas para que con su ejemplo cundiera entre los habitantes de la capital.

Una de las primeras solicitudes presentada correspondió a fray José Viñals, perteneciente al Colegio Apostólico de San Fernando de México, quien se prestó deseoso a ocupar la plaza de capellán de los nuevos batallones. Para lograr este cargo no dudó en escribir al virrey resaltando los servicios prestados en el pasado golpe de estado de 1808. Finalmente el empleo sería para otro religioso, el presbítero Vicente Ramón Hoyos y Cuesta. No hizo falta mayor argumento que recordarle al virrey Venegas los 200 pesos que anualmente donaba para el mantenimiento de las tropas españolas en la guerra de independencia.

Los tenientes coroneles responsables de dirigir los batallones fueron elegidos entre lo más granado de la elite novohispana, respetando el criterio observado en el nombramiento de los oficiales golpistas en 1808, es decir, la división de poderes entre los miembros de los partidos vasco y cántabro y, un reparto escrupuloso entre españoles americanos y europeos. Al mando se encontraban el marqués de San Miguel de Aguayo (1. ${ }^{\circ}$ Bat.), Antonio Bassoco (2. ${ }^{\circ}$ Bat), el conde de las Heras (3. ${ }^{\text {er }}$ Bat.) y el sobrino del virrey y capitán de Caballería Mariano Hidalgo de Luque (Escuadrón de Caballería). Se dispuso que la uniformidad del cuerpo de Patriotas Distinguidos de Fernando VII de México consistiera en casaca azul turquí con collarín, vuelta y forro, encarnados, pantalón con botón blanco y ojaladura de galón de plata en el frente de la casaca, mientras que el Escuadrón de Caballería de Patriotas Distinguidos de Fernando VII vestía casaca y capa azules, chupa, calzón y botón blanco, collarín y vuelta encarnados con una palma y un sable en plata. Respecto al armamento de los batallones de infantería la Junta solicitó al virrey que fuera entregado un fusil a cada miembro e, incluso recomendaron aumentar esta cifra para surtir al resto de la ciudadanía con el fin de repeler un inminente asalto a la capital.

El virrey comprobó que, a pesar del esfuerzo por completar los batallones, su número no llegaba a cubrir los mínimos exigidos $\mathrm{y}$, ante la proximidad del ejército insurgente, emitió un segundo bando en el que mostraba su preocupación al decir que «había pasado un considerable tiempo en que deberían estar completos, como me lo persuadí, viendo a muchas personas de todas clases apresurarse a tener parte en un servicio tan importante a la Patria, pero sabiendo que aún falta un número considerable, y que está per- 
diendo tiempo en su organización y conveniente disciplina; he tenido por oportuno prefijar el término perentorio de ocho días contados desde la fecha, para que se presenten los que no lo hubieren ejecutado, en el concepto de que pasado este plazo, se procederá a llenar dichos Cuerpos por alistamientos forzosos» ${ }^{13}$.

Lejos quedó la imagen de los miles de jóvenes agolpados a las puertas de las oficinas de alistamiento dispuestos a defender el virreinato del enemigo francés. Dos años más tarde y, esta vez ante un enemigo real que acechaba la capital, sus vecinos eludieron su obligación de defenderla ${ }^{14}$. La suerte estaba echada, el futuro de la Nueva España no dependería de los Voluntarios de Fernando VII de ciudad de México.

El 30 de octubre de 1810 se produjo la Batalla del Monte de las Cruces en donde las tropas del coronel Torcuato Trujillo no lograron detener a los 80.000 insurgentes que al mando del capitán Allende ya encontrarían expedito el camino de la capital. Ante el inevitable saqueo de la capital el padre Hidalgo ordenó cambiar de rumbo y abandonar el valle de México. Aunque desconocemos las razones por las que tomó esta controvertida decisión, lo que sí podemos asegurar, es que no lo hizo por temor a los recién formados Voluntarios de Fernando VII, ya que como veremos en páginas siguientes, nunca llegó a ser realmente un garante de la seguridad de la ciudad de México.

Los PRimeros PROBlemas. Dificultades de los batallones PaRa CUBRIR las VACANTES

A pesar de todas las diligencias de los jefes milicianos, a fecha de cinco de enero de 1811, estas unidades no llegaron a completarse, por lo que se decidió incorporar a los numerosos voluntarios foráneos de la capital que, habiéndose alistado, ya habían regresado a sus hogares «los unos con licencia, los más sin ella». Agobiados al no reunir el mínimo de voluntarios sugirieron al virrey que tomase medidas drásticas para poder cumplimentar las unidades. De este modo a los que rechazaran el servicio en diez días, serían mandados a las milicias provinciales $\mathrm{y}$, curiosamente enfatizaban, que tan solo tenían derecho a vestir el uniforme de voluntarios los patriotas que

13 Orden para la organización de batallones de patriotas distinguidos de Fernando VII, de los que es coronel el virrey, México a 5 de octubre de 1810. Hernández y Dávalos, 1878, tomo II, doc. n. ${ }^{\circ} 69$.

14 Ortiz Escamilla, 2000: 27. 
permanecieran a este cuerpo, prohibiendo su uso a todo aquel que tan solo lo portase con fines ostentosos; a estos últimos se les retiraría la vestimenta la primera vez y en caso de reincidir se les sancionaría con una multa de 25 pesos. El incumplimiento del cupo de alistados repercutió en la clase de tropa en quien recayó más servicios de los que les correspondía. Para aligerar estas cargas los jefes de la unidad propusieron al virrey la creación de un cuarto batallón. Si no fueron capaces de cubrir el mínimo en los momentos más difíciles de la vida del virreinato no lo iban a hacer ahora que el peligro insurgente se había reducido. A pesar de las amenazas de reclutamiento forzoso que el virrey lanzó, el cuarto batallón jamás se creó. Algo había que hacer y el 8 de abril de 1811, el virrey, tras escuchar a los miembros de la Junta de alistamiento, decidió que en tres días los tribunales, jefes de oficinas y rectores de los colegios de la capital obligaran a sus dependientes y empleados a incorporarse a estas unidades y por fin crear el tan solicitado cuarto batallón de Infantería.

Una vez más las previsiones de las autoridades no se cumplieron y el número de Voluntarios aptos a conformar los cuerpos patrióticos no llegó ni para dotar a los batallones con los miembros suficientes para las tareas básicas. Venegas, decepcionado, se quejaba de que la «gente distinguida» de la capital que rehuía de su deber de ciudadano y de español. Pero lo que más ofendió al virrey fue cómo muchos de los que no asistían a cumplir sus deberes en los cuarteles seguían paseando por la ciudad con el uniforme de voluntario, por lo que prohibió definitivamente esta vergonzosa práctica. Es curiosa la paradoja, mientras unos no podían comprar el uniforme por razones económicas y querían servir, otros incumplían su deber y se pavoneaban uniformados. La Junta pensó que si la aportación humana no resultaba, al menos la económica podría paliar esta situación. Así en noviembre de 1811, varios tribunales, cuerpos y comunidades contribuyeron, vía donativo voluntario, con la cantidad de 6.225 pesos que se repartieron por partes iguales entre los tres batallones de Infantería y el Escuadrón de Caballería. A pesar de los múltiples problemas citados, sus jefes conservaban la fe en las posibilidades del cuerpo y defendían la idea de que se podía convertir en una unidad competente gracias a una moderna formación dirigida no solo a la tropa sino también a sus propios oficiales. Los incansables jefes informaron al virrey de que «para que los Batallones de Patriotas Distinguidos de Fernando VII reciban la instrucción conveniente sobre la táctica moderna, creemos de mayor obligación exponer a V. E. que será conveniente en mayor concepto crear en las Compañías las clases de segundos tenientes, subtenientes que previene la misma táctica moderna, y que oímos decir se practica con la tropa veterana de la Península, porque 
para la formación son indispensables cuatro oficiales por compañía». Convincentes debieron de ser estas palabras porque tan solo seis días después de su solicitud esta medida fue aprobada por el virrey. A partir de ese momento a cada compañía le fue asignada dos oficiales subalternos más. Es interesante señalar asimismo cómo el virrey hizo que se respetara entre la oficialidad la paridad de americanos y peninsulares. A este respecto decía que: «... donde haya capitán europeo deberán ser americanos el primer teniente y el segundo subteniente, y por el contrario alternando siempre en la que tenga capitán americano».

El marqués de San Miguel de Aguayo, comandante del 1.er Batallón, presentó al virrey el estado en el que se encontraba su mando. La fuerza total a su cargo ascendía a 452 plazas de Patriotas, incluidos sargentos y cabos. De los primeros, 356 disponían de uniforme y 96 carecían de él, por lo que estaban obligados a servir en prevención o retenes. Para cubrir al mes las guardias que se destinaban a la protección del virrey y de la capital novohispana se necesitaban al menos 1.715 hombres, por lo que cada cuatro días debían repetir servicio. El retén resultaba muy molesto para sus componentes, obligados a abandonar sus casas y familias las noches que pernoctaban en el cuartel. El marqués de Aguayo preocupado por estas penalidades exhortó al virrey que buscase una solución que aliviara a sus hombres de tan pesado servicio. La situación era tan crítica que con las bajas por enfermedades y otros accidentes, los Patriotas finalmente debían servir cada tres días. No era fácil convencer a los acomodados capitalinos a que antepusieran la seguridad de la capital a sus propios negocios y empleos. Los continuos y penosos servicios se agravaron por las numerosas excepciones que se produjeron entre los alistados. La mayor parte fueron por motivos de salud; tal y como podemos apreciar en los expedientes que se encuentran en el Archivo General de la Nación de México, en los que los facultativos informaban de las enfermedades y lesiones de sus achacosos pacientes. A estos había que sumar los empleados públicos que solicitaban ser excluidos o directamente no llegar a ser reclutados, amparándose en su condición de funcionarios imprescindibles en la administración. De este modo los empleados de comercio fueron los más castigados ya que durante su servicio ni podían atender sus negocios ni recibían sus jornales.

Ante la imposibilidad de cubrir este déficit, los oficiales voluntarios estaban obligados a localizar entre los distintos barrios de la ciudad a los voluntarios y exigirles que cumplieran con el servicio asignado y, en caso de resistencia, estaban autorizados al uso de la fuerza. Ahora bien, si el designado gozaba de la consideración pública e incumplía con su obligación, se procedía a reclamar su compromiso de un modo más cortés, tal y como actuó el capi- 
tán Mariano de Icaza al escribir a su homólogo el capitán y líder del golpe de estado de 1808, Gabriel Joaquín de Yermo para que mediara ante su primo Gabriel Patricio de Yermo quien rehuía de sus deberes castrenses. Sirva a modo de ejemplo la correspondencia que mantuvieron estos dos oficiales. La primera de las misivas decía de este modo:

Mi estimado Amigo y Señor: El rigor con que en el día se exige el servicio Patriótico y la decadencia de este nuestro $1 .^{\circ}$ Batallón recarga la fatiga a los pocos individuos que lo componen de suerte que se les hace insufrible y a cada momento me están reclamando sobre que apremie a los alistados en la Compañía para que hagan las que les toque por turno, de que no puedo desentenderme sin faltar a la justicia: y siendo comprendidos entre otros el primo de U. Don Gabriel Patricio y su dependiente Larrea, le he de merecer que les haga presente la urgencia del día para que no se excusen a las citas del Servicio que les corresponda.

Crea U. que me es sumamente sensible dar este paso, pero las circunstancias no me permiten prescindir, y espero que conociendo U. esto mismo, tenga la bondad de dispersar y mandar cuanto guste a este su afectísimo Q. S. M. B. Mariano de Icaza ${ }^{15}$.

Gabriel Joaquín de Yermo mostró su desinterés al respecto y recalcó que mientras hubiera ciudadanos que se paseasen tranquilamente por la ciudad sin haber realizado el menor gesto patriótico, su primo Gabriel Patricio había participado activamente en el golpe de estado que destituyó al virrey Iturrigaray:

Mi estimado amigo y Sr.: Es muy justo el reclamo que me dice en la suya de hoy le hacen los Patriotas de la Compañía de lo insufrible que es la fatiga, pues habiendo muchísimos que rechazan paseando en esta capital que no han hecho el menor servicio de los 14 meses que ha se crearon los batallones es natural que aquellos se hallen resentidos y muchos enfermos, como ha sucedió con mi primo D. Gabriel Patricio, pues lo ha hecho muy puntual sin embargo de no ser más que agregado como V. habrá visto por la lista que le mandé original de la junta, a que se agregan otros servicios que ha hecho a la patria, de que no hay muchos ejemplares.

Larrea pensó pasar de la Artillería a la compañía de que es U. Capitán, pero antes de haber hecho ningún servicio en ella, varió de aquel modo de pensar.

Que es cuanto puedo decir a U. sobre el particular. Este su seguro amigo S. S. Q. S. M. B. ${ }^{16}$.

15 Marqués de San Miguel de Aguayo (1810-12), cartas, México, 20 de diciembre de 1811 y 14 de enero de 1812, AGN, Operaciones de Guerra, volumen 765, 1810-1821, fojas 283-326. 16 Idem. 
Informado por su primo, Gabriel Patricio responde al capitán Icaza comunicándole su delicado estado de salud por el que se ve impedido a cumplir con su deber militar. Comprende las difíciles circunstancias que padecen los batallones de Patriotas pero le aconseja que antes de reclamar su presencia, primero habría que hacer volver al servicio a los muchos voluntarios aptos y expeditos que habían sido exonerados. Asimismo no pierde la oportunidad de recordarle que: «... ninguno de ellos se acerca ni con mucha diferencia a los costosos sacrificios que yo he tenido que sufrir en defensa de la buena causa, constantes a S. E. y de que cargo comprobante, sin utilidad alguna personal, y experimentando antes bien quebrantos y atrasos irreparables especialmente en mis haciendas de San Nicolás, de la jurisdicción de Izúcar» ${ }^{17}$.

La situación no resultaba sencilla y el virrey planteó a los cuatro comandantes de los batallones la posibilidad de gravar con un impuesto a los numerosos voluntarios que por necesidad se veían obligados a solicitar licencia para poder salir de la ciudad y hacerse cargo de sus abandonados negocios. Para estos jefes, esta opción resultaba doblemente perjudicial para los Voluntarios, al entender que serían doblemente castigados, por una parte serían reagrupados en las compañías de cada lugar en donde se encontrasen y por otra tendrían que pagar el nuevo gravamen. Impotentes y sin encontrar respuesta a la alarmante falta de personal los comandantes exigieron que los colegiales de San Ildefonso, San Juan Letrán y principalmente del Real Seminario de Minería fueran adiestrados en el manejo de las armas para contribuir en la defensa y orden de la capital ante un posible ataque insurgente. El director del Real Seminario de Minería, el célebre descubridor del wolframio Fausto de Elhúyar, alzó su voz contra esta medida y se quejó amargamente de que mientras los comerciantes se liberaban de los servicios por medio de pago sus alumnos perdían clases. No era sencillo llegar a un acuerdo. El comandante del 2. ${ }^{\circ}$ Batallón Antonio de Bassoco (líder del partido vasco en el Consulado de Comerciantes de la capital) recomendaba al virrey Venegas una alternativa que pudiera satisfacer a ambas partes: «Durante las horas que no sean de estudios acudan puntualmente siempre que fueran llamados a los Cuarteles Patrióticos en el traje que más les acomode con la prevención de que si algunos padres o tutores sacaren colegiales capaces de hacer servicio por excusar hacerlo se den cuenta los rectores para tomar providencia que corresponda». Finalmente y a pesar de las reticencias de Elhúyar, los alumnos del Real Seminario de Minería acudieron a los cuarteles día y medio a la semana para participar de las actividades propias de la milicia. No por ello el director del Real Seminario claudicó y, advirtió, esta vez al nuevo virrey Félix María

\footnotetext{
17 Idem.
} 
Calleja, que sus alumnos sufrían gran retraso académico como consecuencia de las prácticas cuarteleras, por lo que solicitaba que a los colegiales se les exonerase del servicio militar. Según fue desapareciendo el temor a la toma de la capital por las fuerzas rebeldes la tensión entre instituciones académicas y el cuerpo de voluntarios se desvaneció.

Perfil de los Voluntarios de Fernando ViI según el padrón de la Ciudad DE MÉXICO DE 1811

Las autoridades virreinales ya habían manifestado su interés por realizar un padrón que sirviera para actualizar la cada vez mayor población de la ciudad, que para principios de siglo XIX contaba con cerca de 113.000 habitantes. En 1793 el teniente coronel Diego García Conde levantó el Plan General de la ciudad de México, primer paso para obtener una idea más exacta de la capital que continuaría el virrey Venegas con la elaboración del padrón de 1811. Esta responsabilidad recayó en el comandante militar de la plaza Pedro de la Puente, quien delegó en los tenientes de policía para que elaboraran un censo en el que se expresasen conceptos tales como: cuarteles mayores (de los ocho que componían la ciudad), cuarteles menores, manzana, calle, casa, nombre, grupo étnico, origen, país, edad, estado civil, ocupación y finalmente su condición de Voluntario patriota. De estos últimos el número ascendía a 1.416 individuos. El 94,5\% de estos residían en los cuarteles más cercanos al Zócalo, es decir, en las calles con más comercios y tiendas artesanales de la ciudad, de hecho, el $61 \%$ estaban directamente relacionados con el comercio y un $8 \%$ se definían como artesanos. De este censo podemos deducir que, tal como animaba el propio virrey Venegas, se produjo un reparto equitativo entre todos los españoles, tanto americanos como europeos. Respecto al origen de los peninsulares sobresalen los procedentes del norte de España y, tal y como sucediera en el reparto de poder en el Consulado del Comercio de México, entre los partidos cántabro y vasco, igualmente se refleja en este censo: el 25\%, es decir 176 individuos, procedían de Cantabria, igual porcentaje que los nacidos en el País Vasco y Navarra con 175 personas. En orden porcentual del resto de los territorios peninsulares Asturias encabeza esta relación con el 12\% (88 Patriotas) igual cifra que Castilla-La Mancha. Con una menor presencia, Andalucía con 57 personas que representan el 8\%, Galicia y La Rioja con el 6\% (45 Patriotas cada territorio) y 34 voluntarios más del resto de la península. Respecto a los españoles novohispanos se constata que el $82 \%$ de los Voluntarios (472) eran originarios de la intendencia de México, frente a un 16\% procedente de otras demarcaciones. En cuan- 
to a la de edad de los componentes de este cuerpo principalmente estaba comprendida entre los 20 y 30 años (43\% del total), mientras que el segundo grupo lo constituían los voluntarios de entre 30 y 34 años (35\%) seguido de los más mayores con una edad comprendida entre los 35 y 39 años $(15,20 \%)$. A diferencia de la tropa, los oficiales y jefes del cuerpo (17\%) superaban esta última edad. Respecto al estado civil de los Voluntarios la mayoría eran solteros $(69 \%)$ ) frente a un $28 \%$ de casados y un $3 \%$ de viudos. Visto lo anterior podemos concluir que el prototipo de voluntario era la de un joven soltero peninsular dedicado al comercio, residente en los alrededores de la Plaza Mayor ${ }^{18}$.

\section{LA INDISCIPLINA: ORIGEN DE TODOS LOS MALES}

A los numerosos problemas que los batallones de Voluntarios sufrieron hubo que añadir la falta de recursos económicos de sus miembros que incluso, muchos de ellos, no disponían ni de armas ni de uniforme, el abuso de autoridad, la corrupción de los cabos de vista - encargados de localizar a los Patriotas para el servicio y que admitían gratificaciones para exceptuarlos-, la indiferencia $y$, especialmente la indisciplina que convirtió a los voluntarios en un cuerpo prácticamente ingobernable. La Junta se planteó la necesidad de eliminar la figura de los alquilones (sustitutos a sueldo) y, si la situación no

18 Para el análisis de este grupo nos hemos basado en el estudio de los padrones que guarda el Archivo General de la Nación de México: volumen 53, 1811, fojas: 342: Padrón de habitantes de diferentes partes de la Ciudad de México, formado por el teniente Ignacio García Sáenz; Padrón Cuartel Menor, volumen 55, 1812, fojas: 121; Padrón de los habitantes del Cuartel n. ${ }^{\circ} 9$ de la Ciudad de México formado por el teniente de Policía marqués de Salvatierra, volumen 56 1811, fojas: 122; Padrón de los habitantes del Cuartel n. ${ }^{\circ} 10$ de la Ciudad de México, un legajo suelto compuesto de cuatro hojas sueltas sobre: Razón de bautismo y entierros verificados en la parroquia de San Pablo, etc., formado por Francisco Sáenz Escoboza, teniente de Policía, volumen 57, 1811, fojas: 247; Padrón de los habitantes del Cuartel n. ${ }^{\circ} 11$ de la Ciudad de México, volumen 58, 1811, fojas: 167; Padrón de los habitantes del Cuartel n. ${ }^{\circ} 13$ de la Ciudad de México, formado por el teniente Fernando de Hermosa, volumen 59, 1782, fojas: 115; Padrón General del Cuartel Menor n. ${ }^{\circ} 13$ de la Ciudad de México, formado por su alcalde Rafael Morales, volumen 60, 1811, fojas: 417; Padrón de los habitantes del Cuartel n. ${ }^{\circ}$ 14, volumen 61, 1811, fojas: 84; Padrón de los habitantes del Cuartel n. ${ }^{\circ} 15$, volumen 62, 1811, fojas: 92; Padrón de los habitantes del Cuartel Menor n. ${ }^{\circ}$ 16, volumen 64, 1811, fojas: 106; Padrón General de los habitantes del Cuartel n.$^{\circ} 18$, formado por el teniente de Policía conde de la Presa de Jalapa, volumen 66, 1811, fojas: 117; Padrón General de los habitantes del Cuartel n. ${ }^{\circ}$ 21, formado por el teniente José Vicente Olloqui, volumen 67, 1811, foja 67; y Padrón General de los habitantes del Cuartel Menor n. ${ }^{\circ} 22$, formado por el teniente corregidor Ramón del Mazo. 
mejoraba, amenazaron incluso con la extinción de los cuerpos patrióticos. Los viejos fantasmas de la ingobernabilidad y de la violencia arbitraria que supusieron el final de los voluntarios septembrinos volvieron a mostrarse poco tiempo después. En esta ocasión la Junta de alistamiento acusaba directamente al Escuadrón de Caballería al que llegó a tildarlo de temible:

... no hay día que llegan a ella quejas de diferentes clases y sujetos que son o han sido verdaderamente vejados por parte del Escuadrón, que a título de que este completo quiere comprender en su alistamiento general, arbitrario, y tal vez impolítico, a toda población de esta capital. No se exceptúan a sus requerimientos, ni los ancianos, ni los individuos que no han cumplido la edad prevenida para este servicio, ni los exceptuados por V. E. y por esta Junta [...] A los que tienen la fortuna de excepcionarse en el riguroso Tribunal del Escuadrón, se les exigen contribuciones pecuniarias de doce, de diez hasta de dos pesos mensuales, convirtiéndose por consecuencia el desinteresado, distinguido, personal y patriótico servicio de este cuerpo en un servicio mercenario de poca confianza y contra todas las esperanzas y principios de su establecimiento ${ }^{19}$.

Malos hábitos aprendieron los Voluntarios de Fernando VII de sus antecesores los sargentos y cabos del Regimiento urbano de la capital. Algunos de estos oficiales reclutaban soldados fuera de las filas de los empleados de comercio, mientras otros, los menos, trataban de aplicar los reglamentos. Los ricos comerciantes eran sustituidos por sus cajeros y los que no podían cubrir su puesto, al menos contribuían al costo de la mitad o un tercio del servicio de un soldado del Regimiento de Comercio. La práctica de pagar alquilones estaba generalizada, llegándose a pagar hasta un peso diario, el triple de la paga de un soldado regular. Dentro de este corrupto sistema, los sargentos y los cabos del Regimiento que se encargaban de la contratación obtenían un porcentaje de lo ofrecido por el comerciante además de la comisión por encontrar los sustitutos ${ }^{20}$. El profesor Archer dice al respecto que «esto estaba permitido a pesar de la corrupción que podía generar, pues los comerciantes no tenían tiempo para buscarlos por sí. Ocasionalmente los oficiales rechazaban a los individuos inútiles que se presentaban. Casi todos estaban de acuerdo en que los alquilones eran «gente abandonada» que pasaba la mayor parte del tiempo en tabernas y no era posible someterla a disciplina militar, desertaban a menudo, lo que suponía para el contribuyente mercantil la pérdida de cualificados $»^{21}$. 5010 .

19 México, 16 de mayo de 1811, AGN, Instituciones Coloniales, Indiferente Virreinal, caja

20 Archivo General de Indias, Sevilla (AGI), Indiferente General, volumen 19.

21 Archer, 1983: 237-238. 
A pesar de que el reglamento de los Voluntarios ordenaba claramente las funciones y deberes de la tropa y de la oficialidad, el marqués de Aguayo, alertaba de la lamentable situación que vivía este cuerpo miliciano en donde no se respetaba el orden propio de una unidad militar y la insubordinación estaba generalizada: «... en la clase de soldados y un modo indolente infructuoso y débil, de parte de algunos de los Sres. Oficiales, Sargentos y Cabos para cuyo repaso me será sensible en extremos usar de los medios que corrijan y entienda la superioridad ${ }^{22}$. Para poner freno a esta decadencia se instruyó que los capitanes cuidaran escrupulosamente sus compañías para que, con puntualidad, hicieran cumplir a todos los subalternos sus deberes, dando «el servicio que prevengan los Ayudantes no disimulando la menor falta y corrigiendo al que delinquiere con arreglo al artículo $1 .^{\circ}$ y siguientes hasta el $9 .^{\circ}$ título de las ordenanzas militares $\rangle^{23}$. Asimismo se ordenó que cada semana se nombrara a uno de los suboficiales para que se ocupase de los servicios e hiciera cumplir estrictamente las guardias y patrullas que correspondieran a la tropa. Asimismo instruía que los voluntarios que estuvieran libres de servicio y no tuvieran un real y efectivo impedimento debían concurrir al servicio doctrinal. El retén estaría compuesto por un capitán, dos tenientes y subtenientes con sus respectivos sargentos, cabos y 15 soldados.

El recargado servicio de los Voluntarios, sus dificultades de combinar su vida laboral con la militar y por qué no decirlo, su falta de compromiso, provocó que se produjese una de las faltas más graves en el ejercicio de sus cometidos, el abandono de la guardia. El ayudante del 1. ${ }^{\circ}$ Batallón, Jacobo Fernández de Iglesias, informó a su comandante, el marqués de Aguayo, de que el día 18 de julio de 1812, varios miembros de la guardia de la puerta del palacio virreinal habían abandonado su puesto cuando se produjo el relevo. El oficial de guardia, el capitán Alonso, no pudo descubrir quiénes en concreto habían desatendido el servicio por lo que al regresar al cuartel mandó formar a sus hombres y procedió a pasar lista. Sorprendentemente empezaron «a responder unos por otros y por ser tantos no quiso comprometerse castigando a todos, tomando por mejor partido el participarlo» ${ }^{24}$ a su comandante. Para este último: «La causa de que en la tercera compañía (la infractora) se note menos exactitud que en otras proviene de que el capitán de ella deja al arbitrio del cabo de citas, de cuyo favor se me ha informado hace abuso convirtiendo en su provecho algunas cantidades de las que había que dar a los alquilados». El capitán Alonso confirmó lo dicho por su comandante de que

\footnotetext{
22 México, 11 de enero de 1812, AGN, Operaciones de Guerra, volumen 669, 1810-1815.

23 Idem.

24 Idem.
} 
«al menos las dos terceras partes de la tercera compañía eran pagados de los demás del Batallón y el tercer sumamente indecentes y que hoy al retirarme con la guardia me encuentro con la falta de la tercera parte de los 40 que habrá llevado y como fue imposible averiguar quiénes se habían ido por ser alquilados no he tomado providencia para su castigo. Esta falta es y ha sido siempre». No sería el único jefe en denunciar la indisciplina de la tropa. El comandante del Escuadrón de Caballería, conde de Casa Ágreda ${ }^{25}$, responsabilizó al capitán de la primera compañía, José Llaín, de que varios individuos a su mando faltasen a la guardia del Paseo y de que no lograra arrestar a todos los implicados rápidamente, y en consecuencia ordenó el arresto del citado capitán hasta que no apareciesen todos los acusados. La medida, a juicio del oficial, era excesiva, por lo que decidió quejarse a su propio coronel, el virrey:

Un oficial que jamás ha dado nota de su persona y que tiene acreditado, como puede V. E. informarse de todos los individuos de este cuerpo, su exactitud y amor al servicio no puede mirar con indiferencia que se le avergüence y mortifique con la pena de arresto sin haber incurrido en falta que lo haga acreedor de ello; tampoco puede serle indiferente el que el expresado Sr. Comandante lo haya tratado con aspereza por tan débiles motivos a presencia de otros oficiales y cabos, en cuya circunstancia me veo precisado a recurrir a V. R. como a mi Coronel y General para que echose cargo la genial prudencia de V. E. de todo lo ocurrido con consideración a que el asunto debió cuando hubiese justificado motivo para ello, reducirse a los límites de mi casa ${ }^{26}$.

No tardó en llegar la respuesta del comandante, quien escribió al virrey acusando al capitán de haber «acomodado el hecho, omitiendo partes muy sustanciales como por ejemplo, que de 20 individuos pertenecientes a su compañía con servicio en el Paseo de la tarde del Corpus y de ellos, faltaron ocho y ausente el capitán que se encontraba en la búsqueda de los infractores, por lo cual no pudieron presentar honores ante el virrey un día tan señalado por la solemnidad ${ }^{27}$. La opinión del conde de Casa Ágreda respecto al capi-

25 1. ${ }^{\circ}$ Conde de Casa Ágreda. Diego de Ágreda de Tejada Martínez-Cabezón Sainz y Moreno, Caballero de la Orden de Carlos III, obtuvo Real despacho de Hidalguía por la Sala de los Hijosdalgo de la Real Chancillería de Valladolid el 25 de abril de 1798. El condado de Casa de Ágreda (con el Vizcondado previo de Casa de Tejada) fue creado por Real decreto refrendado por el Consejo de Regencia de 26 de mayo de 1811, cuyo Real despacho le fue expedido por la Secretaría de Indias el 9 de junio de 1816.

${ }^{26}$ Conde de Casa de Ágreda. Escuadrón de Patriotas de México. Propuestas para vacantes, despachos de oficiales y solicitudes y peticiones diversas de tropa y oficiales, México, 30 de mayo de 1812, AGN, Operaciones de Guerra, volumen 223, 1812-1816, 341 fojas.

27 Idem. 
tán José Llaín resulta de lo más explícito: «Este individuo, es sumamente inquieto, nada subordinado, que fácilmente se produce con aquellas palabras obscenas, de la gente más ordinaria y desbocada. Por ellas, por su mucho atrevimiento y porque no estimula todo lo que puede a la gente de su compañía para que vaya al Ejército haciéndose notable entre todas la falta, lo tenía apercibido de 4 ó 5 veces, y excuso cuanto puedo las ocasiones pasándole las cosas que no debiera de que tiene V. E. antecedentes». El virrey, en vista de estos enormes problemas, procedió a consultar a su jefe si sería conveniente dividir el Escuadrón en dos comandancias. Ágreda era de la opinión de que la propuesta no conduciría a una mejor disciplina y además conllevaría la ocupación de dos cuarteles con sus guardias de prevención y aumentarían el trabajo y ocupación de los Voluntarios. Pero a lo que realmente no estaba dispuesto el conde era a que otras personas se beneficiasen de su Escuadrón, que mantenía gracias a su dinero. Ágreda no dudó en que su parecer quedara escrito y recordaba al virrey lo citado anteriormente que «este cuerpo se debía en su mayor parte a su pundonor, esfuerzo y dinero, y que si la Caballería patriótica se mantenía juntada y sostenida era gracias a su persona». Contrariamente a lo anterior, la realidad era bien distinta: el cuerpo lo conformaban 359 hombres de todas clases, de ellos 49 sin uniformes ni armas, aptos solamente para patrullas, además de 48 voluntarios entre «agachados, mañosos, huidos y enfermos»y asimismo otros 14 con tan solo uniforme, pero sin armas ni caballo, que eran destinados para prevención, por lo que tan solo quedaban 248 hombres de los que:

[...] llamamos corrientes y solo pueden serlo en su clase los que compartidos ofrecen para cada comandancia, la cantidad de 124 y aunque se juntaron el día del Corpus 241 incluidos oficiales; 18 en Palacio y 13 en prevención sin caballo en que se ha visto la mayor fuerza unida fue por haberlo obligado a buscar prendas prestadas y porque entraron en ella muchos de los viejos de los oficinistas y dados por enfermos que no hacen servicio.

Las compañías $5 .^{\mathrm{a}}$ y $6 .^{\mathrm{a}}$ se formaron de personas pobres, dándoles la mayor parte de auxilios y no reponiéndolas con otros, en breve no podrán hacer servicio. Para vivir los demás individuos, mantener el caballo y poner las armas es necesario todo arte de súplicas, ofertas y persuasiva de que yo me valgo, pero como va durando es natural que desmayen, habiendo además muchos de lo anterior que han de huir al abrirse los caminos, de modo que diariamente se han de disminuir por precisión $^{28}$.

En otro orden de cosas, el desconocimiento de los Voluntarios de las ordenanzas en materia disciplinaria (que incluso utilizaban como eximente), y

28 Ibidem, México, 3 de junio de 1812. 
en vista de que en los batallones no se podía asegurar su disciplina, el virrey determinó que: «Los Comandantes cuiden de que sin la menor dilación sean filiados todos los Patriotas y se les instruya de la Real Ordenanza de Ejército, leyéndola una vez ahora y repitiéndola mensualmente mientras estén sobre las armas, para que de esta manera se impongan de sus obligaciones y de las penas a que se hacen responsables por sus delitos, faltas de disciplina e insubordinación, sin que pueda favorecer en lo sucesivo la ignorancia que aleguen infundadamente» ${ }^{29}$.

Ante la comisión por parte de los voluntarios de numerosas faltas graves e incluso delitos, los comandantes se vieron obligados a celebrar juicios para determinar el alcance de estos y castigar procedentemente a los culpables. Sirva como muestra los dos siguientes casos. José María de la Peña, patriota de la 1. ${ }^{a}$ compañía del 3. ${ }^{\text {er }}$ Batallón, fue acusado de robar una espada a Nicolás Sandoval, compañero de su misma compañía y oficial $3 .^{\circ}$ de los Propios de la capital, durante la noche del 30 de diciembre de 1810 cuando ambos realizaban sus funciones en el Cuartel. Actuó como fiscal el Ayudante mayor, el capitán del $3 .^{\circ}$ Batallón Tomás Antonio de Olarria y después de ser interrogadas las partes y presentar la acusación los testigos, el fiscal dictaminó que, teniendo en cuenta que la madre del patriota de la Peña era una señora viuda decente y él un hombre casado y que el valor de la espada era escaso, se le recluyera en un «convento por seis meses en donde con el ejemplo dedicado por obligación a los ejercicios espirituales, acaso se logrará la corrección de este joven: separándolo previamente del Batallón sin alguna formalidad pública por el estado poco decente en que se halla» ${ }^{30}$. El juez pretendía que la sentencia sirviera de escarnio a los indisciplinados Voluntarios: «Por esto, y para que los Patriotas no crean hasta ahora objetos a las penas de la ordenanza general del Ejército, podrá V. E., si lo tuviera a bien, condenarlo a los seis meses de reclusión que pide el fiscal, entendiéndose en la cárcel de la corte» ${ }^{31}$. De esta manera, el voluntario Peña, joven de 21 años, escribiente en el despacho del abogado Sánchez, recibió una condena de seis meses en la cárcel de la corte y expulsión del cuerpo por indignidad.

29 Lo firmaron los cuatro comandantes de los tres Batallones y de escuadra de Caballería, Marqués de San Miguel de Aguayo, Antonio Bassoco, Sebastián de Heras y Soto y Diego Ágreda.

30 Causas instruidas a individuos del Batallón de Patriotas de Fernando VII. Batallones Patrióticos Distinguidos de Fernando VII. 3. ${ }^{\circ}$ Batallón, México, 29 de abril de 1811, AGN, Indiferente de Guerra, volumen 19: 1811-1812.

31 Idem. 
Un año después, un nuevo caso puso en evidencia al polémico cuerpo de Voluntarios. El soldado José Joaquín Palacios fue acusado de sacar furtivamente a una huérfana menor de edad de la casa de su protectora bajo pretexto de matrimonio. La víctima, una niña llamada María Francisca Lazcano, había quedado a cargo de su tía tras fallecer sus padres en 1807. A pesar de los esfuerzos de la tutora por protegerla, el acusado «la ha combatido con papeles, ruegos, promesas y otras tretas semejantes verificadas desde antes de la muerte de sus padres hasta ahora, todo con el fin de alucinarla» ${ }^{32}$. Hasta el propio padre del acusado, oficial $10^{\circ}$ de la antigua contaduría de Tributos, denunció a su hijo como autor de otro engaño, este cometido años antes cuando sedujo a su propia prima y que fruto de este abuso nació una niña que permanecía con el citado abuelo. En vista de la clara vocación castrense manifestada por el acusado a lo largo del juicio, se le destinó a Cuba en donde serviría en un Regimiento de la isla. Libre de los encantos de su donjuán, la joven «alucinada» regresaría a su domicilio familiar.

\section{Los Voluntarios RECLAMAN EL RELEVo}

El propio mariscal de campo Félix María Calleja, poco antes de ser nombrado virrey a principios de 1813, definió al cuerpo de Patriotas Distinguidos de Fernando VII como de «complicado y violento, y por lo mismo embarazoso en su manejo y poco permanente». El veterano militar conocía muy bien la realidad de este cuerpo y clasificó a sus componentes en dos tipos de personas. La primera «acomodada, de más edad y menos salud que la que conviene al servicio de la clase de soldado en que los más sirven, acostumbrados a incomodidades, cargados de atenciones útiles al estado y necesarias a sus familias, mandados por cabos, sargentos y aun oficiales de clase muy inferior a la suya, y acaso por sus mismos sirvientes; con cuyos vicios no es posible que haya subordinación, exactitud, instrucción, disciplina, ni entusiasmo». Respecto al segundo tipo los define como indigentes; personas «sin medios para vestirse ni subsistir, cargados de familia, precisados a abandonar sus oficios, ocupados casi diariamente, sin sueldo, y reducidos a una espantosa miseria, que hace poco honor al cuerpo, detestable su condición al patriota, que la compara con la del pudiente a quien defiende a costa de los mayores sacrificios, y que en la ocasión se vengará acaso

\footnotetext{
32 Idem.
} 
de lo que se le hace sufrir» ${ }^{33}$. Como podemos apreciar este diferente perfil provocó un sinfín de enfrentamientos y disputas entre los propios Patriotas. Recordaba este militar que «las faltas se repiten incesantemente, los pudientes pagan la fatiga que les toca a los que no lo son tanto, estos utilizan sin hacerla, y la venden a los más miserables, en cuyas manos se deposita nuestra seguridad ${ }^{34}$. A pesar de las del futuro incierto de los Voluntarios, el mariscal confiaba en que el cuerpo de Patriotas podría ser el baluarte defensivo de la capital y la confianza del reino. Calleja, una vez nombrado virrey, emitió un bando en que instaba a la población capitalina a prestar sus servicios en los Distinguidos Patriotas y de este modo proceder al relevo a los milicianos que durante tres años habían velado por la seguridad de la ciudad. El documento decía de este modo:

La Junta de reemplazos de los cuerpos Distinguidos de Patriotas de Fernando VII, erigida por mi Decreto de 21 del corriente como se hizo notorio en los papeles públicos, animada del más activo celo y de las ideas más liberales y generosas, muy conformes a las mías, me ha representado por mi arbitrio, para el logro de los importantes fines de su erección, la siguiente providencia, que aprobada por mí, ordeno se publique por Bando en esta capital.

Por tanto, antes de formar un general alistamiento, parece no solo oportuno, sino justo, citar a los nobles, y generosos Ciudadanos de esta Capital, para que penetrados, como ya están, de la necesidad de reemplazar los referidos cuerpos, de las ideas que tiene el gobierno de mantenerlos en el grado de honor, distinción y decoro, que merecen las circunstancias de los individuos que deben componerlos, y de la nueva obligación que les impone la Constitución política de la Monarquía, acudan por si mismos voluntariamente a ofrecerse y subscribirse dentro del término de ocho días, que han de contarse desde la fecha de éste.

Debe comprenderse en la obligación de presentarse todos los Ciudadanos que tengan diez y seis años cumplidos, incluso los que hayan sido exceptuados por esta Superioridad.

Y para que llegue a noticias de todos, y ocurran en el término de los ocho días a alistarse a las Casas de Cabildo de las nueve a la una de la mañana, y de cuatro a las seis de la tarde, mando se publique por Bando en esta capital ${ }^{35}$.

Las nuevas circunstancias políticas obligaron al virrey a cambiar en mayo de 1815 la denominación de la unidad, pasándose a llamar a partir de ese

33 México, 27 de enero de 1813, AGN, Instituciones coloniales, Indiferente Virreinal, caja 1098, exp. 9 .

34 Idem.

35 Bando que solicita se presenten voluntariamente a los ciudadanos que tengan 16 años cumplidos a ofrecer y suscribirse a los cuerpos de Patriotas mexicanos de Fernando VII, El virrey Calleja, México, 1 de octubre de 1813, AGN, Indiferente Virreinal, caja 4730, exp. 33, 1813, 1 foja. 
momento Fieles Realistas, en clara referencia a la lealtad del virreinato al nuevo orden instaurado tras el retorno de Fernando VII y la abolición de la constitución de 1812. Para esas fechas el peligro de un ataque insurgente a la capital desapareció y los componentes de los batallones Voluntarios fueron excusando su presencia. El citado capitán José Llaín solicitó su excedencia en virtud de: «Que habiendo pedido con el memorial que presenté en agosto del año próximo pasado el que $V$. E. se dignase el concederme mi retiro en consideración a no encontrar de urgente necesidad la personal asistencia al desempeño de mi empleo, por cuanto a que bien castigados y escarmentados los enemigos de la Patria por V. E. en tan repetidos y continuados lances, eran ya despreciables en todos puntos y que habiendo abandonado del todo mis intereses desde el principio de la revolución para dedicarme a los sacrificios que exigía la nación, pudiese de algún modo resarcir algún tanto dedicándome expresamente a ello» ${ }^{36}$.

A finales del gobierno de Calleja el problemático cuerpo de los Voluntarios seguía arrastrando sus profundas deficiencias que fueron mermando su protagonismo en la sociedad capitalina. Con su relevo en el gobierno virreinal por el marino Juan Ruiz de Apodaca (1816-1820) se produjeron importantes cambios que influyeron decisivamente en los batallones de los Fieles Realistas. Las urgentes necesidades obligaron a la Junta de reclutamiento a abrir al resto de la sociedad - es decir, los no Distinguidos- la posibilidad de formar parte de los batallones. Las reformas habían cambiado la composición e incluso el nombre. En 1818 los comandantes de los tres batallones y del Escuadrón de caballería escribieron al virrey Apodaca, informándole de que sus unidades estaban compuestas principalmente por vagos, ociosos e infelices artesanos y que resultaba imposible sustituir un «distinguido» por otro de la misma calidad. A esta clasificación «moral» de los nuevos componentes se le sumó la carencia de recursos para subsistir y «todavía mucho menos para mantenerse por su cuenta», tal y como se requería desde el mismo origen del cuerpo miliciano. Los Fieles realistas mantuvieron la misma estructura implantada por Calleja hasta octubre de 1820 cuando se regularon por medio del Reglamento provisional para la milicia nacional de las Provincias de Ultramar, por el que se reorganizaron y aglutinaron en un solo cuerpo todas las fuerzas militares formadas durante las rebeliones coloniales ${ }^{37}$.

36 Conde de Casa de Ágreda. Escuadrón de Patriotas de México. Propuestas para vacantes, despachos de oficiales y solicitudes y peticiones diversas de tropa y oficiales, México, 13 de enero de 1814, AGN, Operaciones de Guerra, volumen 223, 1812-1816, 341 fojas.

37 Ortiz Escamilla, 1993: 284. 


\section{CONSIDERACIONES FINALES}

Era evidente que los primeros Voluntarios en nada se parecían a estos últimos, ni pertenecían a la misma clase social ni tenían intereses en común. Se puede decir que los batallones de Voluntarios de ciudad de México se «criollizaron» y ya cuando fueron convertidos en milicia nacional en 1820 no dudaron en apoyar el Plan de Iguala por el que México se encaminaría hacia su independencia. ${ }^{38}$ Para desgracia de la futura nación los cuerpos militares mexicanos, tanto regulares como milicianos, heredaron una serie de problemas que ya arrastraban desde al menos del último cuarto de siglo XVIII: el privilegio del fuero militar por el que podían eludir a las autoridades civiles y la búsqueda de la promoción personal en perjuicio de sus obligaciones militares. También somos de la opinión de la profesora Losa Contreras cuando sostiene que los privilegios obtenidos por el ejército novohispano influyeron decisivamente en la creación de la tradición pretoriana de México. ${ }^{39}$

Hemos observado cómo sin la participación de los asaltantes que conformaron el cuerpo de Voluntarios de Fernando VII durante la misma noche de la destitución del virrey, España hubiera perdido seguramente mucho antes su posesión más preciada. Este primer cuerpo patriótico fue disuelto por las autoridades virreinales temerosas de ser víctimas de un nuevo golpe de estado, al considerar que los voluntarios velaban más por sus intereses particulares que por los de la Corona. La preocupante presencia de las tropas insurgentes de Hidalgo y Allende a las puertas de la capital en octubre de 1810 obligó al virrey Venegas a reconstruir este cuerpo con el nombre de Patriotas Voluntarios Distinguidos de Fernando VII, con la misión de proteger la ciudad y a sus temerosos habitantes. Las autoridades virreinales eran conscientes de las limitaciones de esta unidad que, a diferencia de las del ejército regular, la tropa carecía de entrenamiento y sus oficiales de unos mínimos conocimientos militares. Es por ello que en ningún momento se pensara destinar a estas unidades a enfrentarse al enemigo en campo de batalla. Los primeros problemas que se encontraron los organizadores dejaron entrever que los vecinos de la capital novohispana deseaban más ser protegidos que hacerlo ellos mismos. Los alistamientos resultaron un fracaso que no llegó nunca a cubrir las vacantes, cada vez más numerosas por las innumerables licencias concedidas, por lo que se hizo obligado adoptar medidas coercitivas (tales como levas y sorteos) para alcanzar el mínimo necesario para proteger al virrey y la ciudad. La compra de los servicios por los alquilones creó una enfrentada división

\footnotetext{
38 Ortiz Escamilla, 1997: 150.

39 Losa Contreras, 2006: 159.
} 
entre los Patriotas: por una parte los más pudientes, capaces de valerse por sus propios medios, y por el otro, los que no tenían recursos suficientes ni para pagarse el uniforme. El cansancio de los Voluntarios, hartos de cumplir un servicio que les limitaba su vida laboral y familiar, provocó que muchos abandonaran el cuerpo, siendo sustituidos, ya no por «gente decente» sino por miembros de las clases menos favorecidas de la sociedad capitalina.

Finalmente somos de la opinión de que el cuerpo de los Voluntarios de Fernando VII resultó un intento fallido, sin lograr convertirse, tal y como pretendía el mariscal Calleja, en el baluarte defensivo de la capital y la confianza del reino.

Anexo 1. Oficiales de Voluntarios de Fernando VII nombrados EN LA NOCHE DEL 16 DE SEPTIEMBRE DE $1808^{40}$

\begin{tabular}{|c|c|c|c|c|}
\hline & CAPITÁN & TENIENTE & SUBTENIENTE & AYUDANTE \\
\hline $1 .{ }^{\text {a }}$ CÍA. & $\begin{array}{c}\text { JOSÉ MTZ. } \\
\text { BARENQUE }\end{array}$ & MATEO MOZO & AGUSTÍN TAJONAR \\
\hline $2 .{ }^{\text {C CÍA. }}$ & $\begin{array}{c}\text { FRANCISCO } \\
\text { COVIÁN }\end{array}$ & & & \\
\hline $3 .{ }^{a}$ CÍA. & ANTONIO USCOLA & $\begin{array}{c}\text { RAFAEL } \\
\text { CANALIAS }\end{array}$ & $\begin{array}{c}\text { IGNACIO } \\
\text { AMPANEDA }\end{array}$ & JOSÉ URIZAR \\
\hline $4 .{ }^{\circ}$ CÍA. & $\begin{array}{c}\text { FRANCISCO } \\
\text { MAZA }\end{array}$ & ANTONIO ARADA & $\begin{array}{c}\text { DOMINGO } \\
\text { UGARTE }\end{array}$ & HILARIO SOLANO \\
\hline $5 .{ }^{a}$ CÍA. & $\begin{array}{c}\text { SANTIAGO } \\
\text { ECHEVERRIA }\end{array}$ & $\begin{array}{c}\text { PEDRO } \\
\text { MUGUERZA }\end{array}$ & JUAN SALAZAR & JOSÉ LLAÍN \\
\hline
\end{tabular}

40 Ruiz de Gordejuela Urquijo, 2010: 89-112. Entre los oficiales golpistas vinculados anteriormente con la milicia podemos señalar a los capitanes Francisco Covián, Francisco de la Maza -ex oficial de milicias en Tlaxcala-, Antonio de Uscola encargado de la conducción de dinero desde la capital novohispana al puerto de Veracruz y que en cierta forma representaba al Consulado en donde fungía como secretario de la institución, y el subteniente Domingo Ugarte Acha quien fuera alférez del regimiento urbano del comercio de México. A imitación de Gabriel de Yermo dos capitanes montañeses Miguel Garrido y José Martínez Barenque Elguero habían solicitado años antes información de limpieza de sangre, quizás con el claro objetivo de ascender socialmente en un mundo tan cerrado como el novohispano y que creían que con esta acción se lo proporcionaría. También es significativo que varios de estos personajes habían sido anteriormente funcionarios de la administración novohispana como el capitán Manuel Joaquín Bonechea, que fue notario real en Fresnillo, los oficiales de Correos el teniente Antonio de Ojanguren y el subteniente Juan Salazar, y el ayudante José Urízar y Landa y subteniente José Machín Marroquín que fueron alcaldes del crimen de ciudad de México, Agustín Arozqueta que fue nombrado corregidor de Toluca y Manuel Serrano quien fuera guarda de las alcabalas de la capital. 


\begin{tabular}{|c|c|c|c|c|}
\hline & CAPITÁN & TENIENTE & SUBTENIENTE & AYUDANTE \\
\hline 6. CÍA. & $\begin{array}{c}\text { MIGUEL } \\
\text { GALLARDO }\end{array}$ & JOSÉ DEL TORNO & $\begin{array}{c}\text { AGUSTÍN } \\
\text { AROZQUETA }\end{array}$ & $\begin{array}{l}\text { MANUEL } \\
\text { SERRANO }\end{array}$ \\
\hline 7. ${ }^{\mathrm{a}}$ CÍA. & $\begin{array}{l}\text { PEDRO } \\
\text { ZAVALA }\end{array}$ & $\begin{array}{c}\text { ANTONIO } \\
\text { OJANGUREN }\end{array}$ & $\begin{array}{c}\text { MARIANO } \\
\text { GONZÁLEZ. }\end{array}$ & $\begin{array}{c}\text { AGUSTÍN } \\
\text { TORREILLA }\end{array}$ \\
\hline 8. CÍA. & $\begin{array}{c}\text { SEVERINO } \\
\text { LEGORRETA }\end{array}$ & $\begin{array}{c}\text { JOSÉ } \\
\text { DE LEJARZA }\end{array}$ & $\begin{array}{l}\text { MANUEL } \\
\text { HURTADO }\end{array}$ & $\begin{array}{c}\text { MANUEL } \\
\text { DEL FIERRO }\end{array}$ \\
\hline 9. CÍA. & $\begin{array}{c}\text { MANUEL } \\
\text { BONECHEA }\end{array}$ & $\begin{array}{c}\text { AGUSTÍN } \\
\text { DE LA PEN } A\end{array}$ & $\begin{array}{c}\text { JOSÉ } \\
\text { ESTANILLO }\end{array}$ & $\begin{array}{c}\text { MANUEL } \\
\text { HORCASITAS }\end{array}$ \\
\hline 10. ${ }^{\mathrm{a}}$ CÍA. & MANUEL ETORI & JOSÉ MACHÍN & $\begin{array}{l}\text { JOAQUÍN } \\
\text { ROMAÑA }\end{array}$ & JOSÉ LOAZES \\
\hline
\end{tabular}

(En cursiva los naturales del País Vasco y Navarra)

\section{Anexo 2. Reglamento del Cuerpo de Patriotas Distinguidos de Fernando VII de Ciudad de México}

El virrey Venegas se fijó en el Reglamento de los Voluntarios de Cádiz de 1808 para ordenar su unidad y tituló a este como «Ordenanza Militar Provisional que debe observar el Cuerpo de Patriotas Distinguidos de Fernando VII de México». «Jamás he creído - escribía el virrey- que los sujetos que se han presentado a alistarse en los Batallones de Patriotas Distinguidos de Fernando VII, destinados al nobilísimo objeto de mantener la tranquilidad y el orden en esta ciudad y a defenderla de los enemigos en caso de ser atacada, se propusiesen no estar sujetos a ninguna ley militar, y menos a no tener subordinación, sin la cual no hay Milicia, pues es su propiedad característica. Mi deferencia más justa a los Distinguidos y pudientes Patriotas que la componen, creo que ha hecho creer a algunos díscolos, o poco reflexivos, que no están obligados a hacer más que lo que se les antoje; no guardar ningunos respetos ni subordinación, y tomar el servicio militar (el más noble, el primero y más esencial de todas las naciones) como un juguete. En consecuencia he creído, que sin perjudicar el mayor y más digno número de individuos sensatos, y penetrado de estos principios, debo prevenir y dictar los siguientes artículos, que haré cumplir y observar.

1. Los Soldados, Cabos y Sargentos de Patriotas Distinguidos de Fernando VII, serán tratados como Cadetes en los actos de servicio.

2. Cuando estén de servicio o sobre las armas, estarán subordinados a los que los manden (como toda tropa) y harán los mismos honores que esta.

3. Las faltas que en los actos de servicio no pueden ser disimuladas, aunque no es de presumir que Distinguidos individuos incurran en ellas, sin 
embargo, para que nunca se alegue ignorancia, se expresará en los artículos siguientes como serán castigadas o corregidas.

4. Cuando un centinela, Guardia o Destacamento esté frente al enemigo, el que abandonare su puesto, será castigado con la pena de Ordenanza, pues ninguna es fuerte para aquél que faltando a la confianza que de él se hace, expone a todos a ser víctimas del enemigo.

5. El que estando de centinela en otra ocasión la abandonare, sufrirá la pena de estar seis meses en un Castillo, y ser despedido del cuerpo, declarándolo incapaz de empleo ni comisión honorífica.

6. El que abandonare la Guardia o Patrulla sin licencia, sufrirá quince días de arresto en el servicio de la Prevención por la primera vez: treinta días por la segunda, y por la tercera será despedido del cuerpo con vituperio.

7. El que faltare a la subordinación en los actos del servicio, sufrirá las penas referidas en el capítulo anterior.

8. El que concurriese tres veces tarde, o faltare una vez al servicio para que se nombre, tolerará por primera vez diez días de arresto al servicio de la Prevención: por segunda veinte días, y por tercera será despedido con oprobio.

9. Los dueños de casas o negociaciones no impedirán, y antes bien cuidarán de que sus dependientes, hijos y sobrinos, acudan con puntualidad al servicio que les toque; y dichos amos podrán hacer el suyo si fueren Patriotas y les conviniere por dichos dependientes, hijos o sobrinos.

10. Ningún Patriota podrá pasarse de la Compañía en que sirva a otra, aunque sea del propio Batallón, y mucho menos de un Batallón a otro sin licencia de su respectivo comandante.

Finalmente, se tendrán todas las consideraciones debidas a unos sujetos tan Distinguidos, y que con sus personas e intereses atienden a la defensa de la Patria, que tan agradecida debe estar a sus sacrificios, y que a mí son muy aceptos y gratos: solo no es ni será disculpable lo que esencialmente se opone al servicio, y lo haría inútil y ridículo, como queda prevenido. México 16 de diciembre de $1810 »^{41}$.

${ }^{41}$ Copia de la ordenanza militar provisional para el cuerpo de México de patriotas distinguidos de Fernando VII, rey de España, expedida por Francisco Javier Venegas, virrey de la Nueva España en el año de 1810, México a 16 de diciembre de 1810, AGN, Impresos Oficiales, volumen 31, exp. 27, fojas: 197-204. 
BIBLIOGRAFÍA

Alamán, Lucas, Historia de México, México, JUS, 1942.

Anna, Timothy, La caída del gobierno español en la ciudad de México, México, FCE, 1981.

Annino, Antonio, “1808: El ocaso del criollismo en México”, Historia y Política, 19 (Madrid, enero-junio 2008): 39-73.

Archer, Christon, El ejército en el México borbónico (1760-1810), México, Fondo de Cultura Económica, 1983.

Brading, D. A., Mineros y comerciantes en el México borbónico (1763-1810), México, FCE, 1971.

Cruz Baney, Óscar, "Las milicias en la Nueva España: La obra del segundo conde de Revillagigedo (1789-1794)", Estudios de Historia Novohispana, 34 (México, enero-junio 2006): 73-116.

Flores Caballero, Romeo, La contrarrevolución en la independencia, México, El Colegio de México, 1969.

Florescano, Enrique, Memoria Mexicana, México, FCE, 1994.

Gortari Rabiela, Hira de, "Julio-Agosto de 1808: La lealtad mexicana", Historia Mexicana, XXXIX/1 (México, 1989): 181-203.

Guedea, Virginia, “Criollos y Peninsulares”, Tesis de licenciatura, México, Universidad Iberoamericana, 1964.

Guedea, "Los indios Voluntarios de Fernando VII", Estudios de Historia Moderna y Contemporánea de México, 10/123, 1. ${ }^{a}$ parte (México, 1986): 11-83.

Guedea, "El pueblo de México y la política capitalina, 1808-1812", Mexican Studies/ Estudios Mexicanos, 10/1 (Berkeley, 1994): 27-61.

Gutiérrez Escudero, Antonio, "La independencia Hispanoamericana: Predicciones y Precursores", Fernando Navarro Antolín, Orbis Incognitus, Avisos y Legajos del Nuevo Mundo, Homenaje al Profesor Luis Navarro García, Huelva, Universidad de Huelva, 2007: 269-292.

Hamill, Hugh M., “¡Vencer o morir por la patria! La invasión de España y algunas consecuencias para México, 1808-1810”, Josefina Zoraida Vázquez, Interpretaciones de la Independencia de México, México, Editorial Patria, 1997: 71-101.

Hernández y Dávalos, J. E., Colección de documentos para la historia de la guerra de independencia de México de 1808 a 1821, México, Biblioteca del Sistema Postal de la República Mexicana, 1878. www.pim.unam.mx/catalogos/hyd/HYDII (Fecha de consulta 02-10-2014). 
Hernández Ruigómez, Manuel, "El primer paso del proceso independentista mexicano: el contragolpe de Gabriel de Yermo (1808)", Revista de Indias, XLI/165-166 (Madrid, 1981): 541-601.

Ladd, Doris, La nobleza mexicana en la época de la independencia, 1780-1826, México, FCE, 1984.

Lafuente Ferrari, Enrique, El virrey Iturrigaray y los orígenes de la independencia de México, Madrid, 1941.

Landavazo Arias, Marco Antonio, Máscara de Fernando VII. Discurso e imaginario monárquico en una época de crisis. Nueva España, 1808-1822, México, El Colegio de México/Universidad Michoacana de San Nicolás de Hidalgo, El Colegio de Michoacán, 2001.

León Borja, István Szászdi, "El fuero militar en el ejército borbónico hispano”. Cuadernos de Historia, 15 (Córdoba, Argentina, 2005): 311-329.

Lerdo de Tejada, Miguel M., Apuntes históricos de la heroica ciudad de Veracruz, tomo II, México, Imprenta de Vicente García Torres, 1857.

Losa Contreras, Carmen, "La formación de las milicias urbanas en la Nueva España", Anuario de la facultad de Derecho (UCM), XXIV (Madrid, 2006): 177-214.

Marchena, Juan, "Reformas Borbónicas y poder popular en la América de las Luces. El temor al pueblo en armas a fines del período colonial", Anales de Historia Contemporánea, 8 (Murcia, 1990-1992): 187-202.

Marchena, Juan, Caballero Gómez, Gumersindo y Torres Arriaza, Diego, El Ejército de América antes de la Independencia. Ejército regular y milicias americanas. Estudio Histórico. Banco de Datos de Hojas de servicio y uniformes, Madrid, Fundación Mapfre Tavera, 2005.

McAlister, Lyle, El fuero militar en la Nueva España (1764-1800), México, Instituto de Investigaciones Jurídicas/UNAM, 1982.

Mier y Terán, Fray José Servando Teresa, La Historia de la Revoluciones de Nueva España, México, 1813.

Miranda, José, Las ideas y las instituciones políticas mexicanas, vol. I (1521-1820), México, UNAM, 1978.

Morales Padrón, Francisco, Diario de Don Francisco de Saavedra, Sevilla, CSIC, 2004.

Ortiz Escamilla, Juan, "Las fuerzas militares y el proyecto de estado en México, 1767-1835". Alicia Hernández y Manuel Miño (coord.), Cincuenta años de Historia de México, México, El Colegio de México, vol. II, 1991: 261-282.

Ortiz Escamilla, Juan, Guerra y gobierno. Los pueblos y la independencia de México, México/Sevilla, Instituto Mora-El Colegio de México/Universidad Internacional de Andalucía, Universidad de Sevilla, 1997. 
Ortiz Escamilla, Juan, "La ciudad amenazada, el control social y la autocrítica del poder. La guerra civil de 1810-182", Relaciones, 21/84 (Zamora, otoño 2000): $15-58$.

Real Díaz, José Joaquín y Heredia Herrera, Antonia M., "José de Iturrigaray (18031808)", José Antonio Calderón Quijano, Virreyes de Nueva España (1798-1808), Sevilla, Escuela de estudios hispano-americanos de Sevilla, 2 tomos, 1972: 182331.

Rodríguez, Jaime E., El Proceso de la Independencia de México, México, Instituto Mora, 1992.

Rodríguez, "De súbditos de la Corona a ciudadanos republicanos: el papel de los autonomistas en la Independencia de México", Josefina Zoraida Vázquez, Interpretaciones de la Independencia de México, México, Nueva Imagen, 1997: 33-69.

Ruiz de Gordejuela Urquijo, Jesús, "200 años del golpe de Estado de Gabriel de Yermo", Juan Bosco Amores (ed.), X Jornadas de Estudios Históricos, Las Independencias americanas: ¿un proceso imaginario?, Vitoria, Universidad del País Vasco, 2010: 89-112.

Ruiz de Gordejuela, El vizcaino Gabriel de Yermo y los voluntarios de Fernando VII, México, INEHRM, 2012.

Salaverría e Yrure, José Manuel, "Relación o historia de los primeros movimientos de la Insurrección de Nueva España, y prisión de su Virrey D. José de Iturrigaray", Boletín del Archivo General de la Nación de México, XII/1 (México, 1941): 88-91.

Salazar Anaya, Delia (coord.), Imágenes de los emigrantes en la ciudad de México, 1753-1910, México, Plaza y Valdés/CONACULTA/INAH, 2002.

Suárez, Santiago, Las Milicias, instituciones militares hispanoamericanas, Caracas, Academia Nacional de Historia, 1984.

Valle del Pavón, Guillermina, "Participación de los mercaderes del Consulado de México en el golpe de 1808", Carmen Collado (coord.), Miradas recurrentes. La ciudad de México en los siglos XIX y XX, México, Instituto Luis Mora, 2004: 147-163.

Villoro, Luis, El proceso ideológico de la revolución de independencia, México, CONACULTA, 1999.

Zavala, Lorenzo de, Ensayo crítico de las revoluciones de México desde 1808 hasta 1830, París, Dupont y G. Laguionie, 1831.

Fecha de recepción: 19 de febrero de 2013.

Fecha de aprobación: 8 de junio de 2013. 


\section{The Volunteers of Ferdinand VII in Mexico City. Bulwark of the Capital and Credibility of the Kingdom?}

This research aims to approach Fernando VII's Urban Militia Volunteers in Mexico City, firstly as shock troops in the coup of September 16, 1808 and two years later as a safe keeper in the viceregal capital until its dissolution on the eve of Mexican independence. Thanks to unpublished primary sources we have been able to delve into the life of this controversial military body marked by scandals and serious internal problems and discover if it really was the bulwark of the capital and the credibility of the kingdom as Viceroy Calleja, his colonel, intended.

KeY words: Volunteers of Fernando VII; Mexico City; urban militias; coup d'état; insurgency; public order. 